University of New Hampshire

University of New Hampshire Scholars' Repository

Center for Coastal and Ocean Mapping

Center for Coastal and Ocean Mapping

2016

\title{
Western Gulf of Maine Bathymetry and Backscatter Synthesis
}

Larry G. Ward

University of New Hampshire, Igward@ad.unh.edu

Paul Johnson

University of New Hampshire, pjohnson@ccom.unh.edu

Erin Nagel

University of New Hampshire, enagel@ccom.unh.edu

Zachary S. McAvoy

University of New Hampshire, Zachary.McAvoy@unh.edu

Maxlimer Coromoto Vallee-Anziani

Follow this and additional works at: https://scholars.unh.edu/ccom

\section{Recommended Citation}

Ward, L.G., Johnson, P., Nagel, E., McAvoy, Z.S., and Vallee-Anziani, M., 2016, Western Gulf of Maine Bathymetry and Backscatter Synthesis: BOEM/New Hampshire Cooperative Agreement (Contract M14AC00010) Technical Report, Department of Interior, Bureau of Ocean Energy Management, Marine Minerals Division, 45600 Woodland Road, Sterling, VA, 20166, 19 pp. https://dx.doi.org/10.34051/p/ 2021.27

This Report is brought to you for free and open access by the Center for Coastal and Ocean Mapping at University of New Hampshire Scholars' Repository. It has been accepted for inclusion in Center for Coastal and Ocean Mapping by an authorized administrator of University of New Hampshire Scholars' Repository. For more information, please contact Scholarly.Communication@unh.edu. 


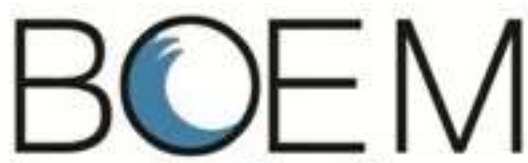

Bureau of Ocean Energy Management

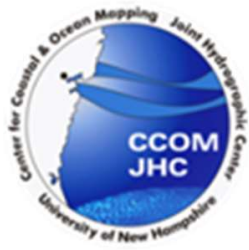

BOEM/New Hampshire Cooperative Agreement (Contract M14ACO0010) Technical Report

\section{Western Gulf of Maine Bathymetry and Backscatter Synthesis}

By Ward, L.G., Johnson, P., Nagel, E., McAvoy, Z.S., and Vallee-Anziani, M.

University of New Hampshire Center for Coastal and Ocean Mapping/Joint Hydrographic Center 24 Colovos Road, Durham, NH 03824

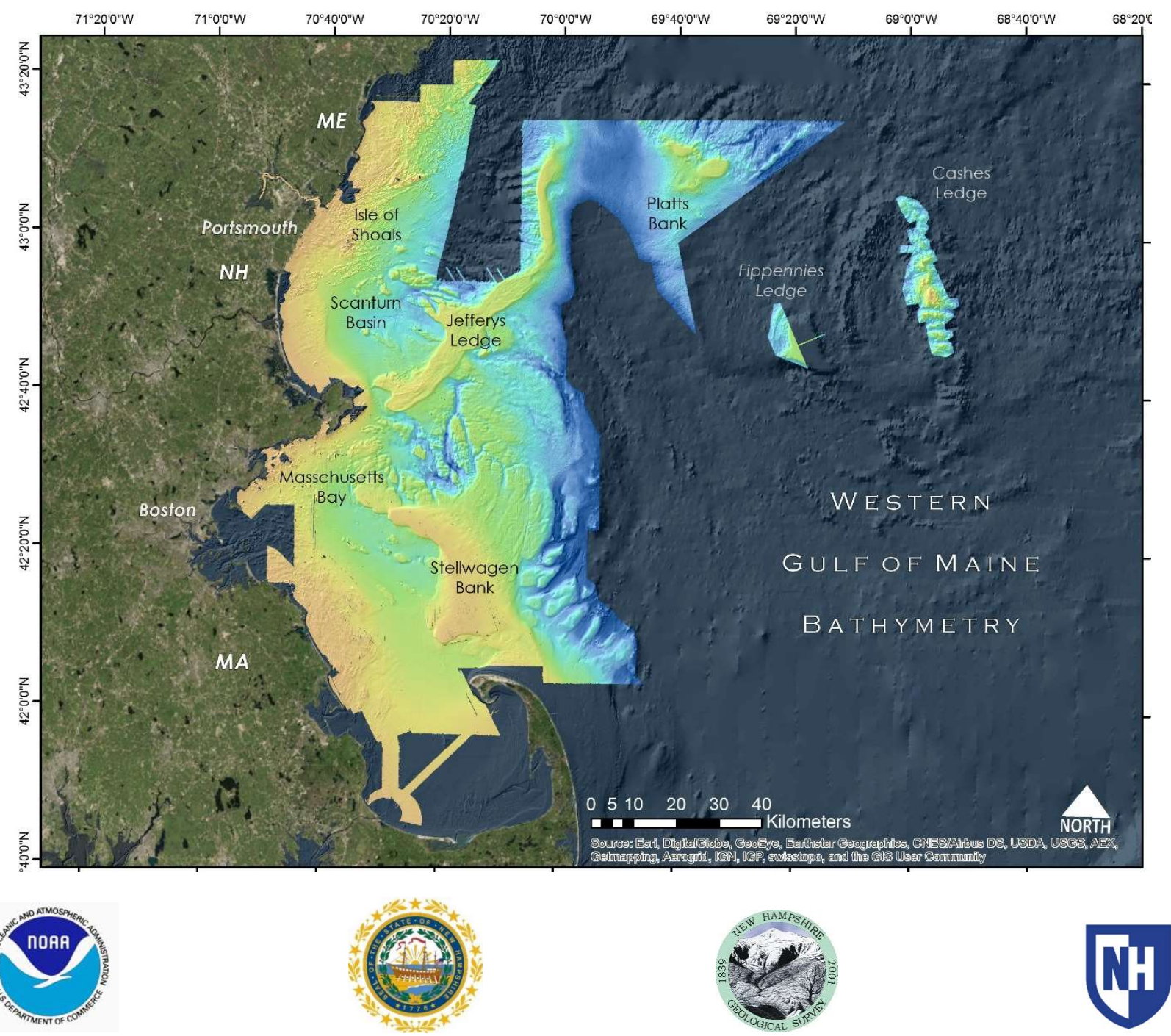




\section{Acknowledgements}

The development of the Western Gulf of Maine Bathymetry and Backscatter Synthesis was supported by the Bureau of Ocean Energy Management Award Number M14AC00010 and University of New Hampshire/National Oceanic and Atmospheric Administration Joint Hydrographic Center Award Number NA10NOS4000073.

We gratefully acknowledge the assistance provided by NOAA National Ocean Survey in providing hydrographic and backscatter survey data. In particular, we would like to thank Castle Parker and Marilyn Schluter (Atlantic Hydrographic Branch), LTJG David Rodziewicz (National Centers for Environmental Information, NCEI; formerly NGDC), and LTCD Mathew Jaskoski (Office of the Coast Survey, Hydrographic Surveys Division). We would like to express our appreciation to LTDR Samuel Greenaway and Glen Rice (NOAA Office of the Coast Survey, Coast Survey Development Laboratory), and Val Schmidt (University of New Hampshire Center for Coastal and Ocean Mapping/Joint Hydrographic Center) for their help in obtaining and processing backscatter surveys, as well as very helpful insights into analysis of the data. Finally, we would like to acknowledge Jennifer Crosby and Colleen Mitchell for their patience and efforts in developing and maintaining the website.

\section{Map Coordinate System, Projection and Datum}

Coordinate System: WGS 1984 UTM Zone 19N

Projection: Transverse Mercator

Horizontal Datum: WGS 1984

Vertical Datum: MLLW

\section{WGOM Bathymetry and Backscatter Website}

http://ccom.unh.edu/project/wgom-bathbackscatter

\section{Recommended Citation}

Ward, L.G., Johnson, P., Nagel, E., McAvoy, Z.S., and Vallee-Anziani, M., 2016, Western Gulf of Maine Bathymetry and Backscatter Synthesis: BOEM/New Hampshire Cooperative Agreement (Contract M14ACO0010) Technical Report, Department of Interior, Bureau of Ocean Energy Management, Marine Minerals Division, 45600 Woodland Road, Sterling, VA, 20166, 19 pp.

https://dx.doi.org/10.34051/p/2021.27 


\section{Table of Contents}

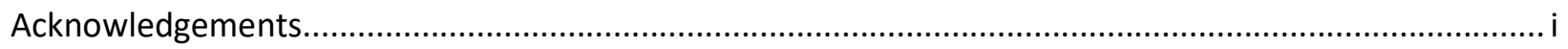

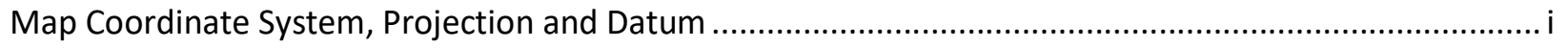

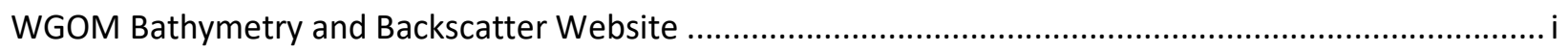

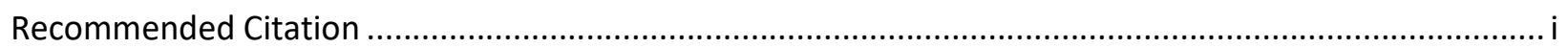

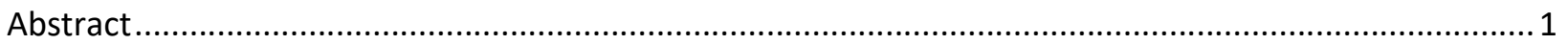

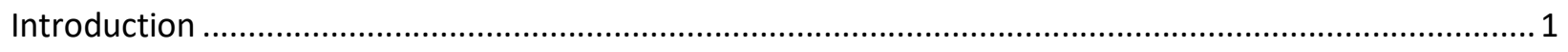

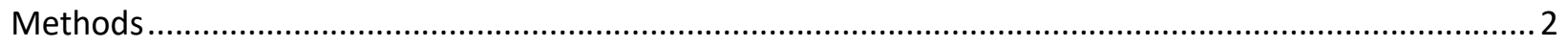

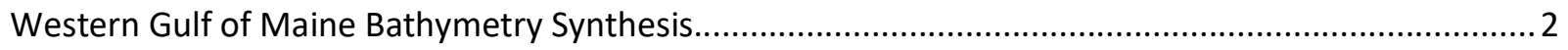

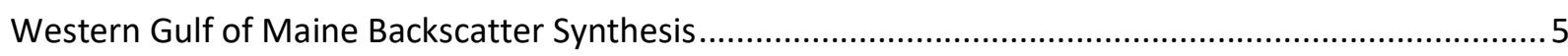

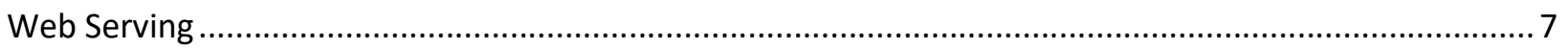

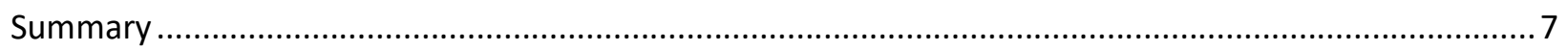

Appendix 1: Metadata for multibeam acoustics surveys used to construct the Western Gulf of Maine Bathymetry and Backscatter Synthesis......................................................................................... 11

\section{List of Figures}

Figure 1. Location map of the multibeam echosounder surveys included in the Western Gulf of Maine Bathymetry and Backscatter Synthesis. Additional information about the surveys is given in Appendix 1 and on the University of New Hampshire Center for Coastal and Ocean Mapping/Joint Hydrographic Center web site (http://ccom.unh.edu/project/wgom-bathbackscatter) ............................................. 3

Figure 2. Western Gulf of Maine Bathymetry Synthesis showing the high resolution multibeam

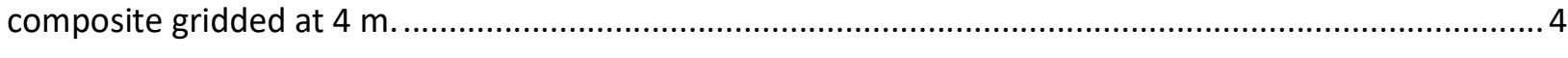

Figure 3. Western Gulf of Maine Bathymetry Synthesis showing regional bathymetry and high resolution

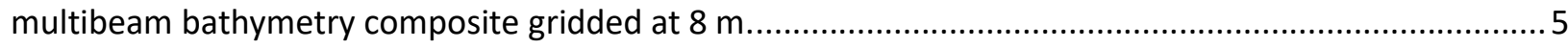

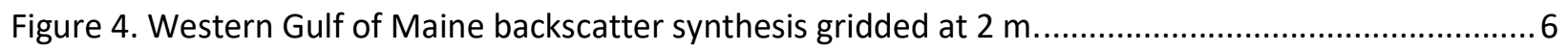


Figure 5. High resolution bathymetry of the region between the Isles of Shoals and the New Hampshire coast. Many of the northwest-southeast trending features are marine modified glacial features that extend onto shore. The color ramp was modified to enhance the display of features. ............................ 8

Figure 6. High resolution bathymetry offshore of the New Hampshire coast showing extensive bedrock outcrops and remnant glacial features closer to shore. The color ramp was modified to enhance the display of features...

Figure 7. High resolution bathymetry seaward of the Isles of Shoals showing the complexity of the seafloor. The color ramp was modified to enhance the display of features. 10 


\title{
Western Gulf of Maine Bathymetry and Backscatter Synthesis
}

By Ward, L.G., Johnson, P., Nagel, E., McAvoy, Z.S. and Vallee-Anziani, M.

University of New Hampshire Center for Coastal and Ocean Mapping/Joint Hydrographic Center

\begin{abstract}
In July 2014 a Cooperative Agreement between the Bureau of Ocean Energy Management, the University of New Hampshire Center for Coastal and Ocean Mapping, and the New Hampshire Geological Survey was developed to assess the potential sand and gravel resources on the New Hampshire shelf and vicinity for the primary purpose of beach nourishment to enhance coastal resiliency. Of major importance to the effort was the development of high resolution bathymetric maps of the region to provide an understanding of the seafloor and to be used as a base for subsequent mapping products. Fortunately, over the last decade a number of high resolution multibeam echosounder bathymetric surveys were completed in the Western Gulf of Maine including the New Hampshire shelf. In addition, many of these multibeam echosounder surveys collected backscatter, which is the intensity of the returned acoustic signal from the seafloor and often reveals a great deal of information about the characteristics of the substrate.
\end{abstract}

Utilizing the high resolution multibeam echosounder bathymetry, as well as several older extant surveys, a synthesis was constructed for the Western Gulf of Maine. The original surveys used in this compilation were gridded over a large range $(0.50$ to $25 \mathrm{~m})$. Therefore, the surveys were regridded at $4 \mathrm{~m}$ and $8 \mathrm{~m}$ for map development. Composites were also constructed of multibeam echosounder backscatter for the Western Gulf of Maine (gridded at $2 \mathrm{~m}$ ). However, due to the difficulties of combining varying surveys, the synthesis for the backscatter surveys was limited to a region off New Hampshire.

The composites for the Western Gulf of Maine Bathymetry and Backscatter Synthesis are presently available through the Center for Coastal and Ocean Mapping/Joint Hydrographic Center website at http://ccom.unh.edu/project/wgom-bathbackscatter.

\section{Introduction}

The overarching goal of the Cooperative Agreement between the Bureau of Ocean Energy Management (BOEM), the University of New Hampshire (UNH) Center for Coastal and Ocean Mapping/Joint Hydrographic Center (CCOM/JHC), and the New Hampshire Geological Survey (NHGS) is to delineate and map potential sand and gravel deposits on the New Hampshire shelf. Central to this effort is high resolution bathymetry of the study area to facilitate mapping and understanding the surficial geology and sediment distribution, as well as the shallow subsurface stratigraphy. Therefore, all available high resolution multibeam echosounder (MBES) bathymetry for the Western Gulf of Maine (WGOM) was synthesized and presented as a composite in a GIS environment (Figure 1 and Appendix 1). 
Another extremely useful product from MBES surveys is the associated backscatter. Backscatter is the strength of the acoustic signal that returns to the transponder and is strongly affected by complex interactions with seafloor properties, such as sediment texture, roughness, or biota. In order to develop a composite of MBES backscatter, a subset of available MBES surveys was assembled for the New Hampshire coast and vicinity (Figure 1 and Appendix 1). Due to varying frequencies, different systems, and dynamic ranges of the backscatter intensity values resulting from combining multiple backscatter surveys, the range of pixel intensity values were normalized and standardized to create a seamless backscatter mosaic image. Thus, the original backscatter intensity values are no longer available. However, with the exception of a few areas, the final product is very useful for assessing seafloor characteristics detected with MBES backscatter.

\section{Methods}

\section{Western Gulf of Maine Bathymetry Synthesis}

More than sixty MBES surveys, conducted by a number of different agencies including the National Ocean and Atmospheric Administration (NOAA) National Ocean Survey (NOS), the United States Geological Survey (USGS), the UNH CCOM/JHC, the Gulf of Maine Marine Institute (GOMMI), the United States Army Corps of Engineers (USACE), Maine Coastal Mapping Initiative, and private organizations (e.g., Science Applications International Corporation, Inc., SAIC), were used to construct the bathymetry synthesis. In addition, sweep single beam data was included for a small area inside Portsmouth Harbor. Details of the surveys and their locations are given in Appendix 1 and Figure 1.

The original MBES surveys used in this compilation were gridded over a large range, varying from $0.5 \mathrm{~m}$ to $25 \mathrm{~m}$. In addition, a regional compilation that included older surveys that are of a much lower resolution (e.g., single beam echosounder survey gridded at $40 \mathrm{~m}$ ) was also used in the synthesis. The highest resolution source data was downloaded by survey and mosaicked in ESRI ArcGIS software to maintain the highest resolution grid for internal analysis and storage. To produce more uniform composites, the mosaic was resampled and exported as 32-bit GeoTiffs

(Figure 2). A synthesis grid of the all the MBES surveys was resampled to a $4 \mathrm{~m}$ fixed grid and a second regional composite was resampled to an $8 \mathrm{~m}$ fixed grid using ESRI ArcGIS (Figure 3). 


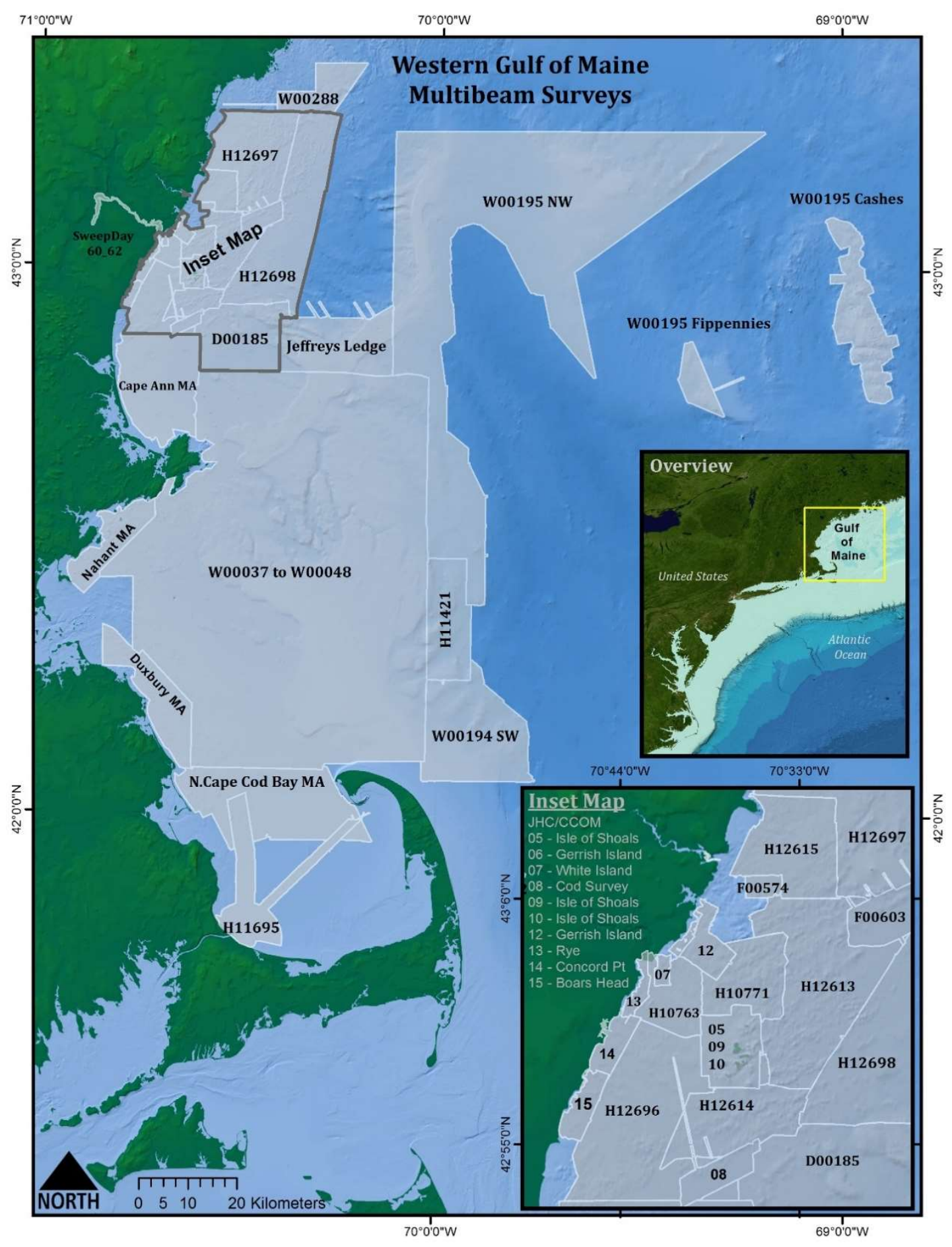

Figure 1. Location map of the multibeam echosounder surveys included in the Western Gulf of Maine Bathymetry and Backscatter Synthesis. Additional information about the surveys is given in Appendix 1 and on the University of New Hampshire Center for Coastal and Ocean Mapping/Joint Hydrographic Center web site (http://ccom.unh.edu/project/wgom-bathbackscatter). 


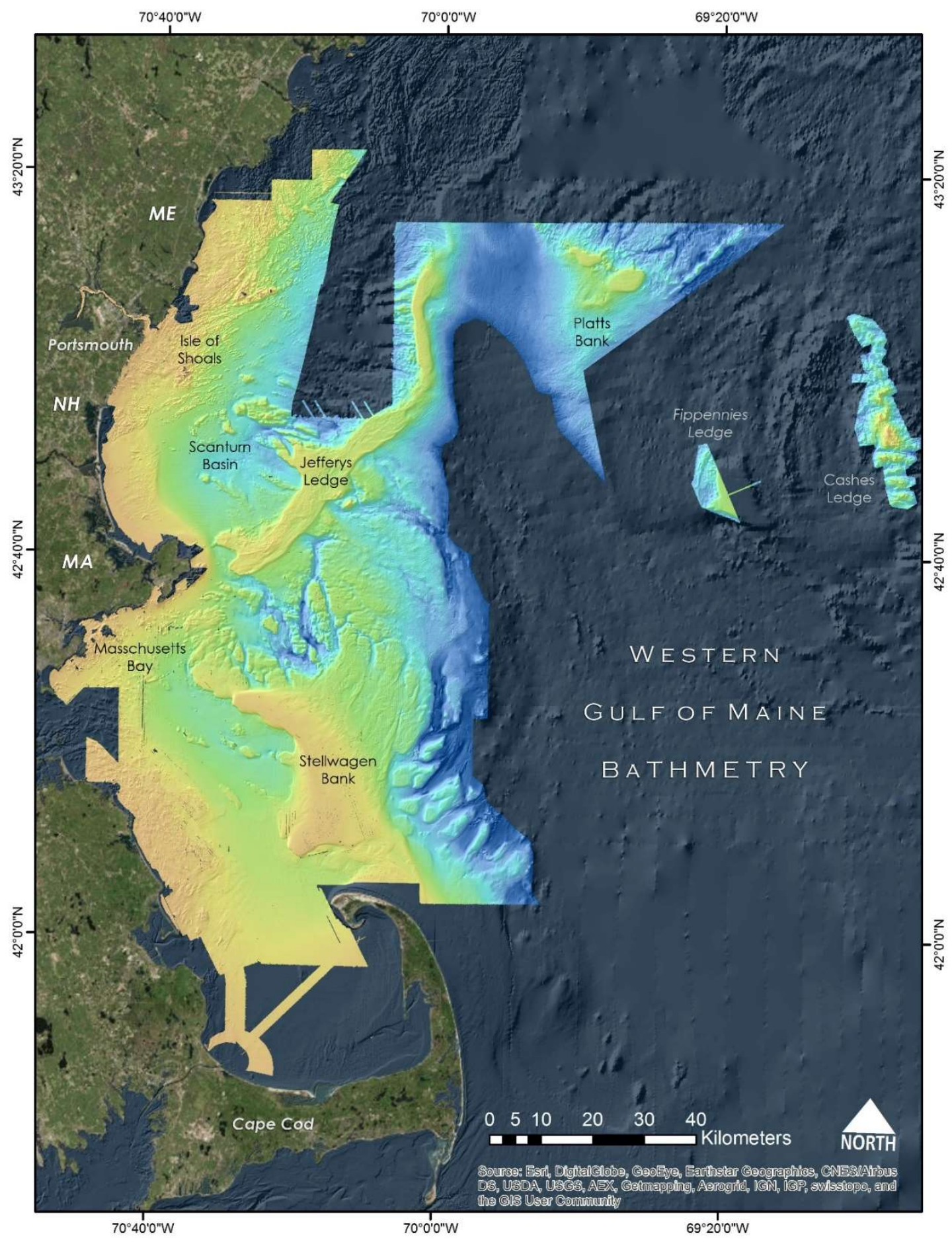

Figure 2. Western Gulf of Maine Bathymetry Synthesis showing the high resolution multibeam composite gridded at $4 \mathrm{~m}$. 


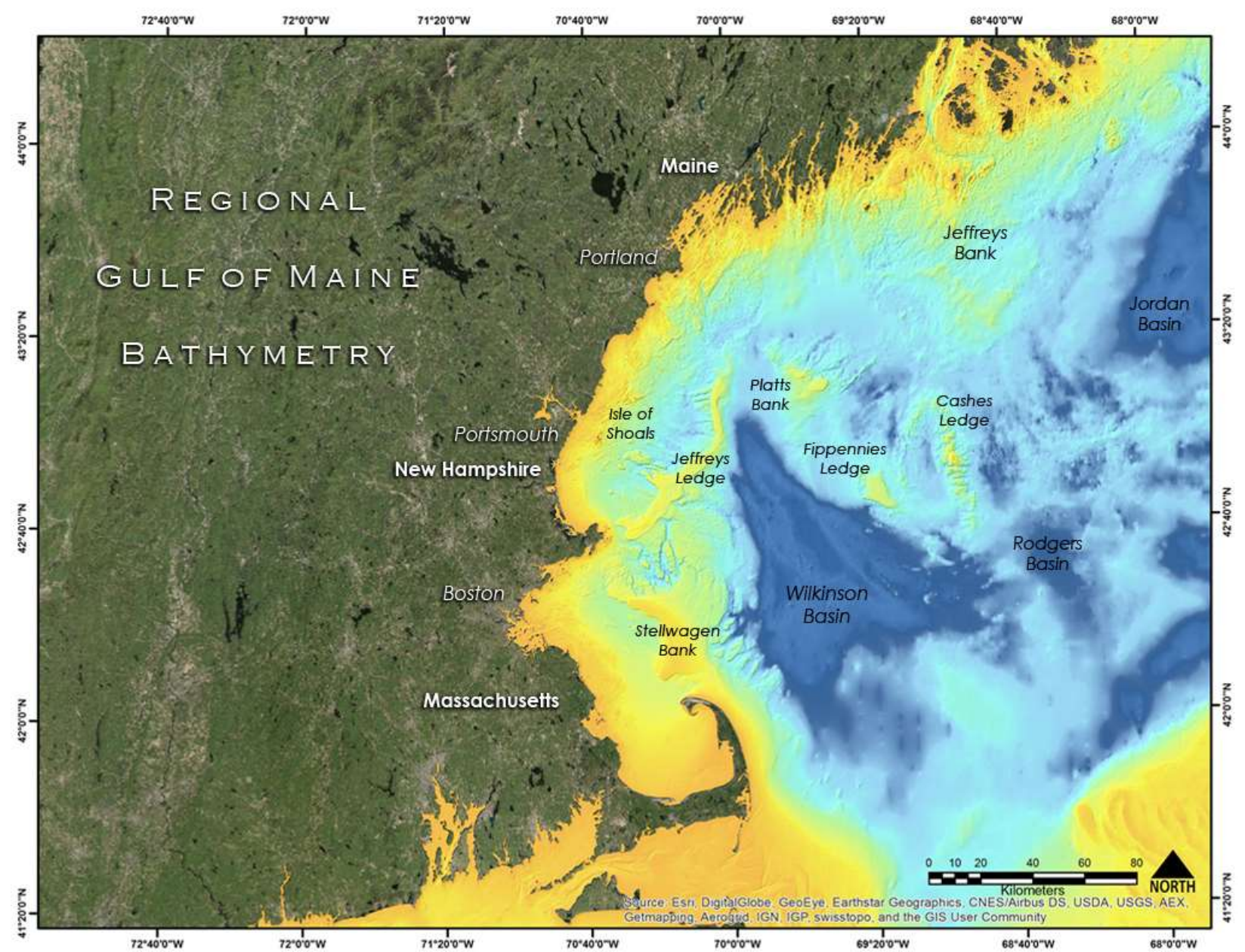

Figure 3. Western Gulf of Maine Bathymetry Synthesis showing regional bathymetry and high resolution multibeam bathymetry composite gridded at $8 \mathrm{~m}$.

\section{Western Gulf of Maine Backscatter Synthesis}

The WGOM backscatter synthesis was assembled using MBES surveys conducted by NOS and UNH CCOM/JHC. No attempt was made to include all of the MBES surveys in the region due to the difficulties of combining varying datasets. Instead, a subset (twelve) for a region off of New Hampshire was chosen (Figure 1 and Appendix 1).

The UNH CCOM/JHC surveys were processed by survey in QPS Fledermaus Geocoder Toolbox (FMGT). However, some of the NOS backscatter mosaics used in this compilation contained residual artifacts that interfered with interpretation of the seafloor characteristics and required pre-processing. The NOS surveys that required additional processing were conducted with dual Reson 7125 MBES. The dual head system was not calibrated and, consequently, offsets between the heads needed to be manually applied during the backscatter processing stages. After preprocessing, the NOS surveys were then processed in CARIS and FMGT. HDCS (hydrographic data cleaning system) data was converted to a GSF (generic sensor format) in Caris HIPS/SIPS and 
combined with raw s7k files in FMGT. Each NOS survey was deconstructed by port and starboard MBES, where applicable. Since artifacts remained for each head, the port and starboard records for each survey were also individually deconstructed by characteristics that would isolate a consistent backscatter return. This included survey day, depth, navigation and complexity of survey lines, homogenous bottom type, or the occurrence of saturation. Offsets between port and starboard and between survey days were calculated and applied, as well as absorption coefficients by survey day. Using ERSI ArcGIS, the backscatter surveys were then standardized and rescaled using a $Z$ score normalization method and mosaicked.

Ultimately, a mosaic was built that minimized the artifacts and allowed visual interpretation. However, the result is a qualitative product showing high and low reflectivity that is somewhat inconsistent across surveys with different frequencies. As a result, quantitative analysis using the backscatter mosaic is not possible. However, the UNH CCOM/JHC surveys can be used for quantitative analysis (Figure 4).

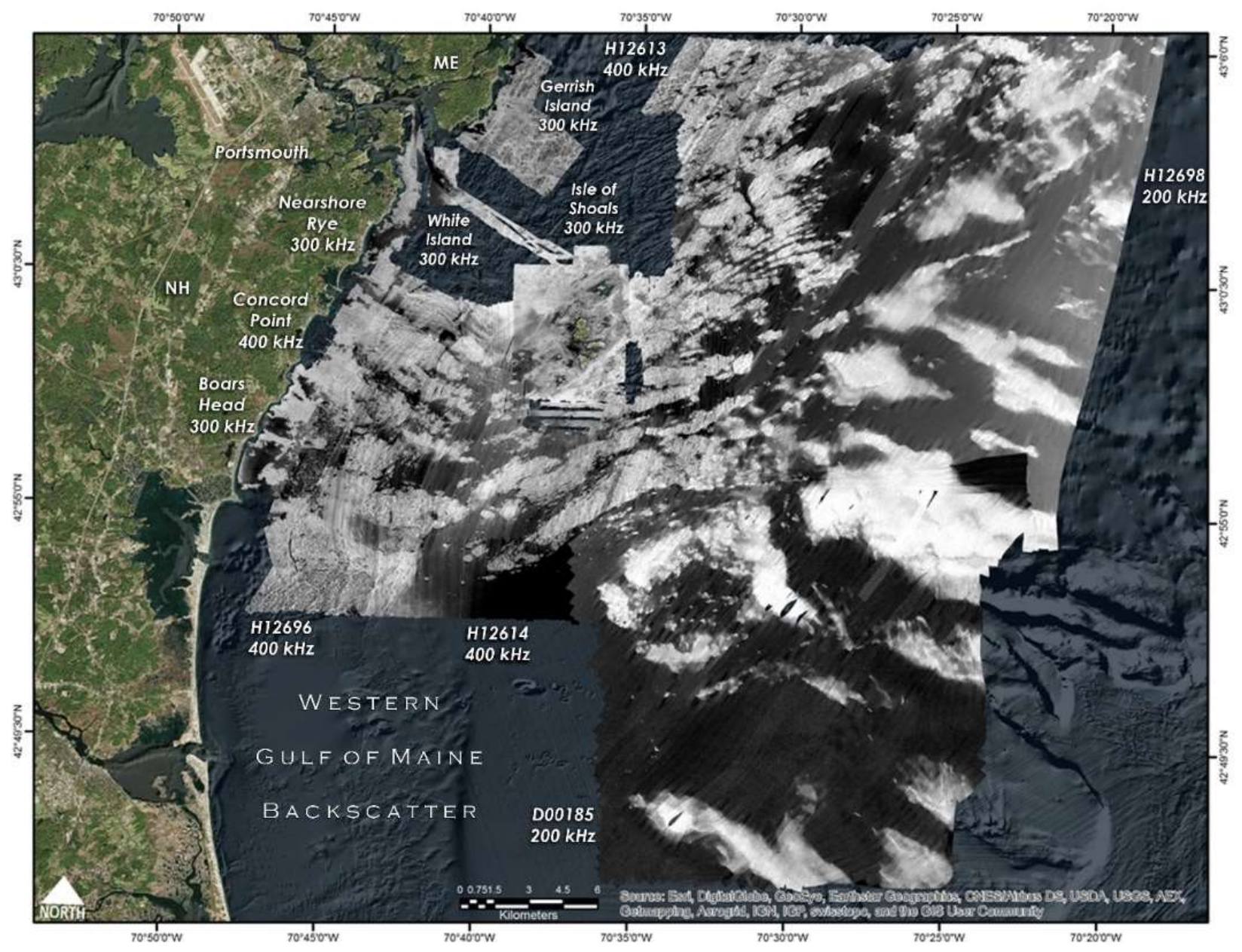

Figure 4. Western Gulf of Maine backscatter synthesis gridded at $2 \mathrm{~m}$. 


\section{Web Serving}

The WGOM Bathymetry and Backscatter Synthesis is available through the UNH CCOM/JHC website at http://ccom.unh.edu/project/wgom-bathbackscatter. The synthesis is web-served using ArcGIS Server/ArcGIS Portal and rendered with web served dynamic interactive maps written in JavaScript. The interactive maps can display the multibeam synthesis, the backscatter synthesis, and query information on each of the surveys or grids (e.g., original gridding, survey source, and other relevant information).

\section{Summary}

A very large and diverse set of bathymetric data including single beam and MBES surveys was successfully brought together and combined into maps that maintained the bathymetry at the highest possible resolution for each survey (Figure 1), as well as a bathymetric synthesis for the WGOM re-gridded at $4 \mathrm{~m}$ and a bathymetric synthesis gridded at $8 \mathrm{~m}$ (Figures 2 and 3). The bathymetry synthesis presenting the $4 \mathrm{~m}$ re-gridded survey uses only the high resolution MBES surveys, while the $8 \mathrm{~m}$ synthesis includes lower resolution bathymetry, but completes the coverage of the study region. Similarly, the backscatter from selected MBES surveys was synthesized for a region off the coast of New Hampshire that included surveys by the UNH $\mathrm{CCOM} / \mathrm{JHC}$ and NOS (Figure 4). Although developing a backscatter synthesis was challenging, a very useful product for qualitative analysis was produced. The $4 \mathrm{~m}$ and $8 \mathrm{~m}$ bathymetric synthesis and the backscatter are web served along with the pertinent metadata.

Collectively, these products provide excellent bathymetric coverage of the WGOM and backscatter for the New Hampshire shelf and vicinity and provide a base for multiple studies including seafloor morphology, sediments, and habitats. Examples of the quality and resolution of the bathymetry and backscatter are exemplified by the enlargements of the bathymetry survey re-gridded at $4 \mathrm{~m}$ (Figures 5, 6 and 7). 


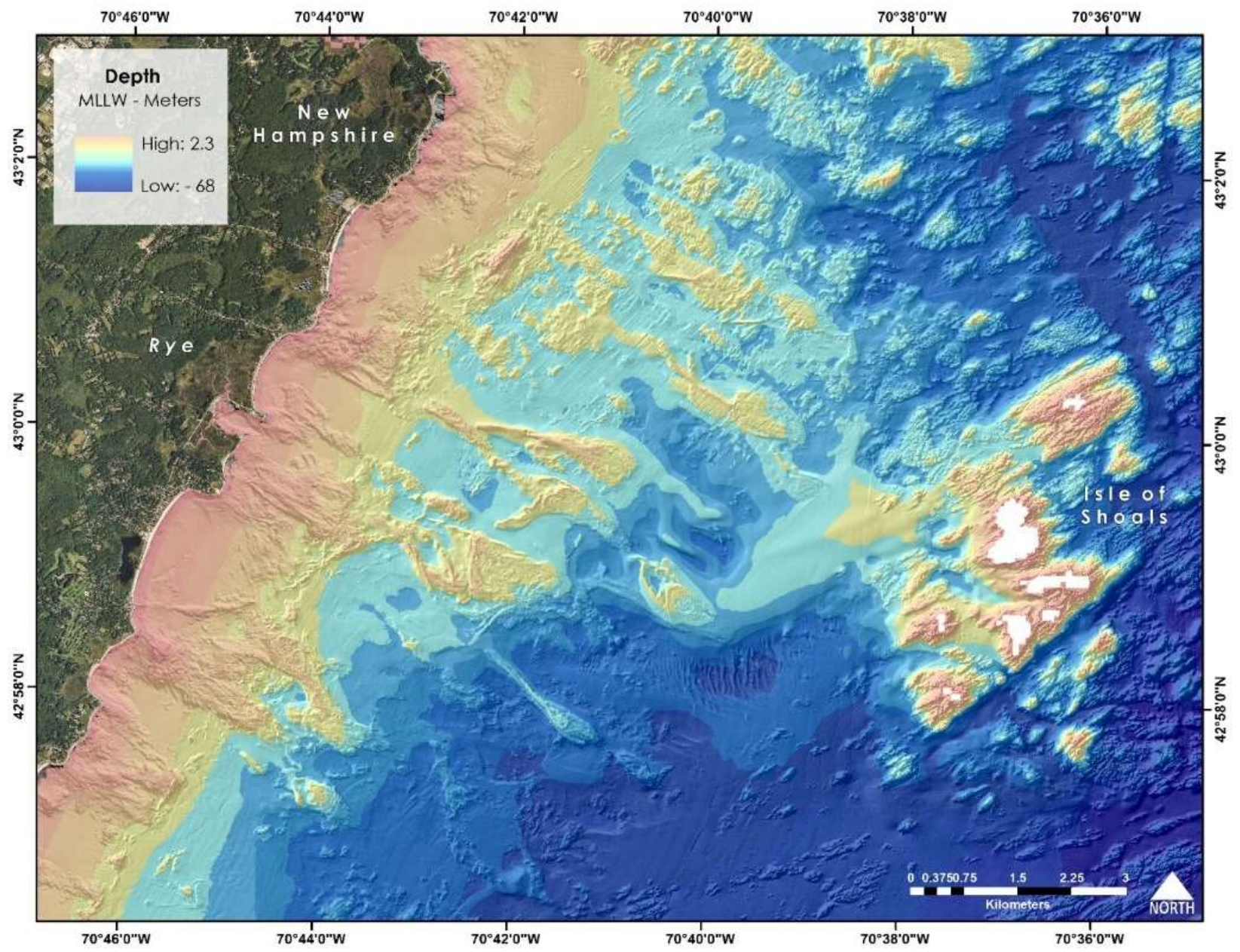

Figure 5. High resolution bathymetry of the region between the Isles of Shoals and the New Hampshire coast. Many of the northwest-southeast trending features are marine modified glacial features that extend onto shore. The color ramp was modified to enhance the display of features. 


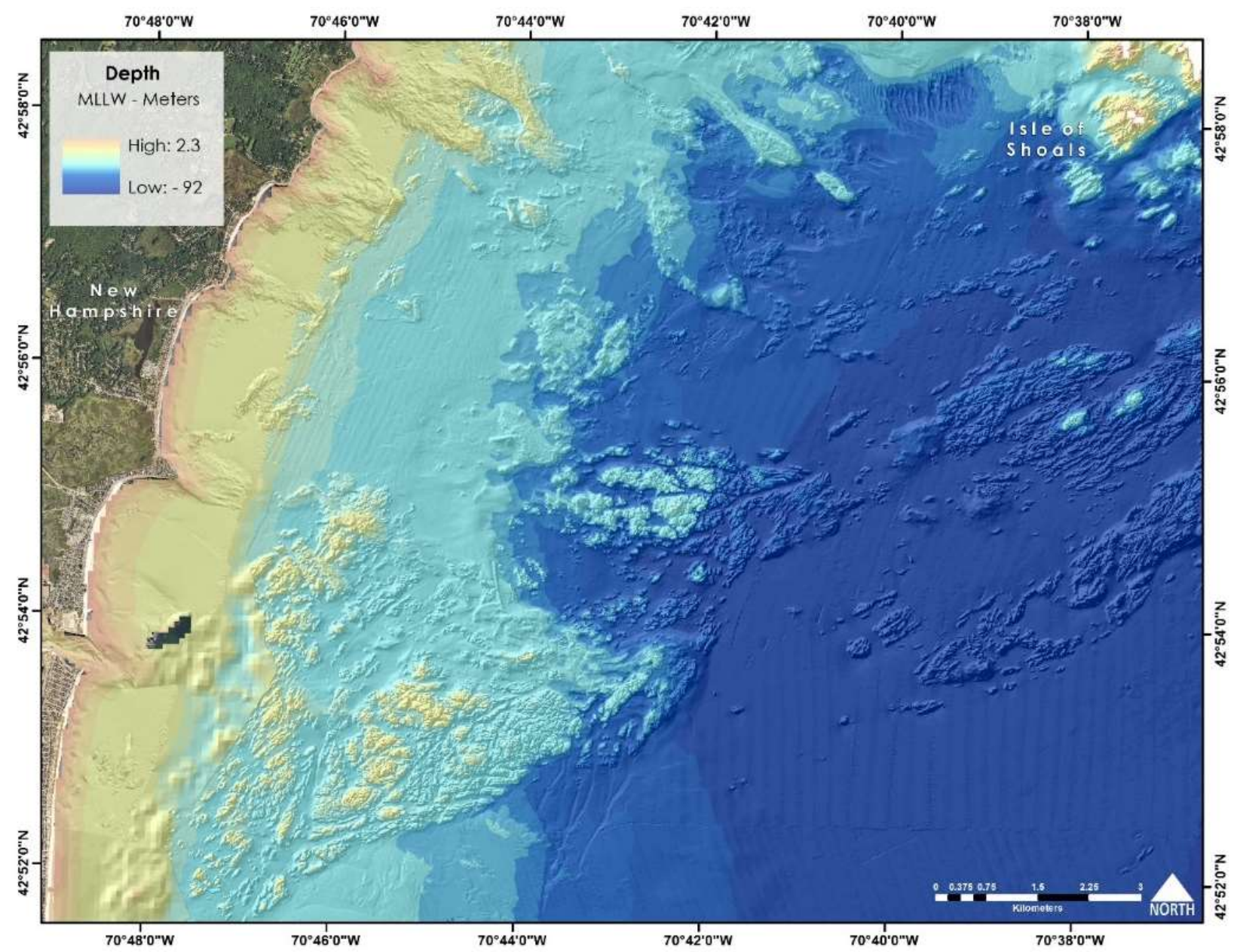

Figure 6. High resolution bathymetry offshore of the New Hampshire coast showing extensive bedrock outcrops and remnant glacial features closer to shore. The color ramp was modified to enhance the display of features. 


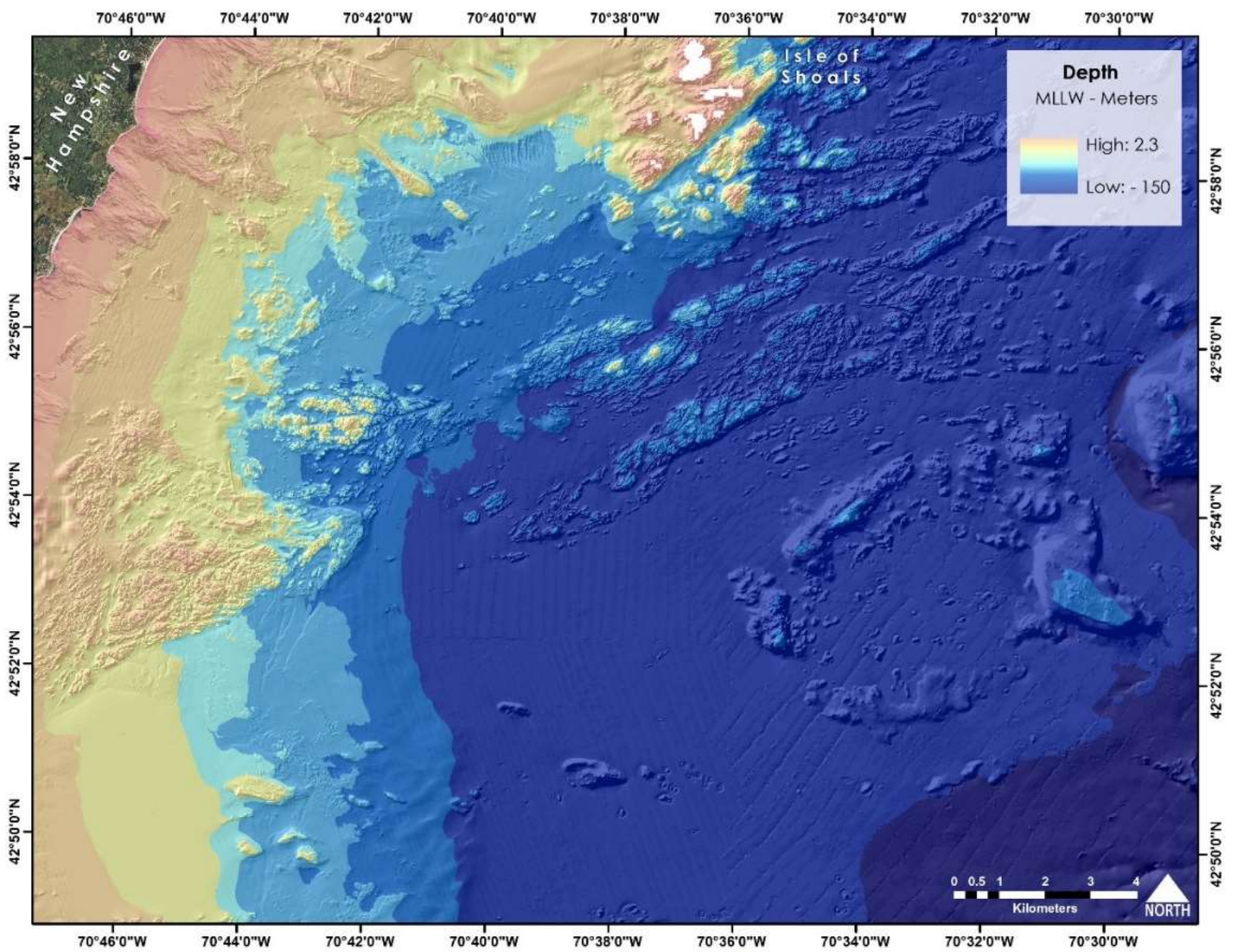

Figure 7. High resolution bathymetry seaward of the Isles of Shoals showing the complexity of the seafloor. The color ramp was modified to enhance the display of features. 


\section{Appendix 1: Metadata for multibeam acoustics surveys used to construct the Western Gulf of Maine Bathymetry and Backscatter Synthesis}

\begin{tabular}{|c|c|c|c|c|c|c|c|c|}
\hline Survey & Survey Year & Agency & Frequency & $\begin{array}{l}\text { Multibeam } \\
\text { System }\end{array}$ & $\begin{array}{c}\text { Highest } \\
\text { Resolution } \\
\text { Available }\end{array}$ & $\begin{array}{c}\text { Multibeam \& } \\
\text { Backscatter } \\
\text { Data } \\
\text { Availability } \\
\text { on NCEI } \\
\end{array}$ & $\begin{array}{l}\text { Included in } \\
\text { the } \\
\text { Backscatter } \\
\text { Mosaic }\end{array}$ & $\begin{array}{c}\text { Included in } \\
\text { Regional } \\
\text { Bathymetric } \\
\text { Synthesis }\end{array}$ \\
\hline $\begin{array}{c}\text { Boon Island } \\
\text { Summer } \\
\text { Hydro }\end{array}$ & 2011 & CCOM & $200 / 400 \mathrm{kHz}$ & Reson 7125 & $2 m$ & No & No & Yes \\
\hline $\begin{array}{l}\text { Castine } \\
\text { Harbor and } \\
\text { Bagaduce } \\
\text { River } \\
\text { Summer } \\
\text { Hydro }\end{array}$ & 2008 & CCOM & $293 / 307 \mathrm{kHz}$ & $\begin{array}{c}\text { Kongsberg } \\
\text { EM3002 Dual } \\
\text { Head }\end{array}$ & $50 \mathrm{~cm}$ & No & No & Yes \\
\hline $\begin{array}{c}\text { Cod Survey } \\
\text { Summer } \\
\text { Hydro }\end{array}$ & 2008 & CCOM & N/A & N/A & $1 \mathrm{~m}$ & No & No & Yes \\
\hline $\begin{array}{l}\text { Concord } \\
\text { Point } \\
\text { Summer } \\
\text { Hydro }\end{array}$ & 2014 & CCOM & $200-400 \mathrm{kHz}$ & $\begin{array}{l}\text { Kongsberg } \\
\text { EM2040 }\end{array}$ & $1 \mathrm{~m}$ & No & Yes & Yes \\
\hline $\begin{array}{c}\text { Isle Of Shoals } \\
\text { Summer } \\
\text { Hydro }\end{array}$ & 2010 & CCOM & $293 / 307 \mathrm{kHz}$ & $\begin{array}{c}\text { Kongsberg } \\
\text { EM3002 Dual } \\
\text { Head }\end{array}$ & $1 \mathrm{~m}$ & No & Yes & Yes \\
\hline $\begin{array}{c}\text { Isle Of Shoals } \\
\text { Summer } \\
\text { Hydro }\end{array}$ & 2005 & CCOM & $293 / 307 \mathrm{kHz}$ & $\begin{array}{c}\text { Kongsberg } \\
\text { EM3002 Dual } \\
\text { Head }\end{array}$ & $1 \mathrm{~m}$ & No & Yes & Yes \\
\hline $\begin{array}{c}\text { Jeffreys } \\
\text { Ledge } 8101\end{array}$ & 2002 & CCOM & $240 \mathrm{kHz}$ & Reson 8101 & $5 \mathrm{~m}$ & No & No & Yes \\
\hline
\end{tabular}




\begin{tabular}{|c|c|c|c|c|c|c|c|c|}
\hline Survey & Survey Year & Agency & Frequency & $\begin{array}{l}\text { Multibeam } \\
\text { System }\end{array}$ & $\begin{array}{l}\text { Highest } \\
\text { Resolution } \\
\text { Available }\end{array}$ & $\begin{array}{c}\text { Multibeam \& } \\
\text { Backscatter } \\
\text { Data } \\
\text { Availability } \\
\text { on NCEI }\end{array}$ & $\begin{array}{l}\text { Included in } \\
\text { the } \\
\text { Backscatter } \\
\text { Mosaic }\end{array}$ & $\begin{array}{c}\text { Included in } \\
\text { Regional } \\
\text { Bathymetric } \\
\text { Synthesis }\end{array}$ \\
\hline W00276 & 2007 & CCOM & $293 / 307 \mathrm{kHz}$ & $\begin{array}{c}\text { Kongsberg } \\
\text { EM3002 Dual } \\
\text { Head }\end{array}$ & $1 \mathrm{~m}$ & .BAG & Yes & Yes \\
\hline W00277 & 2007 & CCOM & $293 / 307 \mathrm{kHz}$ & $\begin{array}{c}\text { Kongsberg } \\
\text { EM3002 Dual } \\
\text { Head }\end{array}$ & $50 \mathrm{~cm}$ & .BAG & No & Yes \\
\hline $\begin{array}{c}\text { Sweep Day } \\
60 \_62\end{array}$ & 2000 & CCOM & N/A & $\mathrm{N} / \mathrm{A}$ & $1 \mathrm{~m}$ & No & No & Yes \\
\hline W00178 & 2006 & CCOM & $300 \mathrm{kHz}$ & $\begin{array}{l}\text { Kongsberg } \\
\text { EM3002 }\end{array}$ & $1 \mathrm{~m}$ & .BAG & No & Yes \\
\hline W00206 & 2009 & CCOM & $293 / 307 \mathrm{kHz}$ & $\begin{array}{c}\text { Kongsberg } \\
\text { EM3002 Dual } \\
\text { Head }\end{array}$ & $1 \mathrm{~m}$ & .BAG & Yes & Yes \\
\hline W00244 & 2012 & cCOM & $300 \mathrm{kHz}$ & $\begin{array}{l}\text { Kongsberg } \\
\text { EM2040 }\end{array}$ & $1 \mathrm{~m}$ & .BAG & No & Yes \\
\hline $\begin{array}{c}\text { York Summer } \\
\text { Hydro }\end{array}$ & 2011 & CCOM & N/A & $\mathrm{N} / \mathrm{A}$ & $2 m$ & No & Yes & Yes \\
\hline H10771_1 & 1997 & NOAA & $455 \mathrm{kHz}$ & Reson 9003 & $3 m$ &. $\mathrm{XYZ}$ & No & Yes \\
\hline H10771_2 & 1997 & NOAA & $455 \mathrm{kHz}$ & Reson 9003 & $10 \mathrm{~m}$ &. $\mathrm{XYZ}$ & No & Yes \\
\hline H11014 & 2000 & NOAA & $240 \mathrm{kHz}$ & Reson 8101 & $1 \mathrm{~m}$ &. $\mathrm{XYZ}$ & No & Yes \\
\hline $\mathrm{H} 11277$ & 2003 & NOAA & $\begin{array}{c}240 \mathrm{kHz} \& \\
455 \mathrm{kHz}\end{array}$ & $\begin{array}{c}\text { Reson } 8101 \\
\quad \& 8125 \\
\end{array}$ & $50 \mathrm{~cm}$ & .BAG & No & Yes \\
\hline H11296_1 & 2005 & NOAA & $\mathrm{N} / \mathrm{A}$ & $\begin{array}{c}\text { SHOALS- } \\
1000 T \\
\text { Bathymetric } \\
\text { LiDAR }\end{array}$ & $5 m$ & .BAG & No & Yes \\
\hline
\end{tabular}




\begin{tabular}{|c|c|c|c|c|c|c|c|c|}
\hline Survey & Survey Year & Agency & Frequency & $\begin{array}{l}\text { Multibeam } \\
\text { System }\end{array}$ & $\begin{array}{l}\text { Highest } \\
\text { Resolution } \\
\text { Available }\end{array}$ & $\begin{array}{c}\text { Multibeam \& } \\
\text { Backscatter } \\
\text { Data } \\
\text { Availability } \\
\text { on NCEI }\end{array}$ & $\begin{array}{l}\text { Included in } \\
\text { the } \\
\text { Backscatter } \\
\text { Mosaic }\end{array}$ & $\begin{array}{c}\text { Included in } \\
\text { Regional } \\
\text { Bathymetric } \\
\text { Synthesis }\end{array}$ \\
\hline H11296_3 & 2005 & NOAA & N/A & $\begin{array}{c}\text { SHOALS- } \\
\text { 1000T } \\
\text { Bathymetric } \\
\text { LiDAR }\end{array}$ & $5 m$ & .BAG & No & Yes \\
\hline H11421 & 2005 & NOAA & $95 \mathrm{kHz}$ & $\begin{array}{l}\text { Kongsberg } \\
\text { EM1002 }\end{array}$ & $6 m$ & .BAG & No & Yes \\
\hline H11467 & 2005 & NOAA & $300 \mathrm{kHz}$ & $\begin{array}{c}\text { Kongsberg } \\
\text { EM3000 }\end{array}$ & $1 \mathrm{~m}$ & .BAG & No & Yes \\
\hline H11636 & 2007 & NOAA & $300 \mathrm{kHz}$ & $\begin{array}{l}\text { Kongsberg } \\
\text { EM3002 }\end{array}$ & $2 m$ & .BAG & No & Yes \\
\hline H11695_1 & 2007 & NOAA & $\begin{array}{c}200 / 400 \mathrm{kHz} \\
240 \mathrm{kHz} \& \\
455 \mathrm{kHz}\end{array}$ & $\begin{array}{l}\text { Reson 7125, } \\
8101 \text { \& } 8125\end{array}$ & $3 m$ & .BAG & No & Yes \\
\hline H11695_1 & 2007 & NOAA & $\begin{array}{l}200 / 400 \mathrm{kHz}, \\
240 / 455 \mathrm{kHz}\end{array}$ & $\begin{array}{l}\text { Reson 7125, } \\
8101 \text { \& } 8125\end{array}$ & $70 \mathrm{~cm}$ & .BAG & No & Yes \\
\hline H11695_2 & 2007 & NOAA & $\begin{array}{l}200 / 400 \mathrm{kHz}, \\
240 / 455 \mathrm{kHz}\end{array}$ & $\begin{array}{l}\text { Reson 7125, } \\
8101 \& 8125 \\
\end{array}$ & $1 \mathrm{~m}$ & .BAG & No & Yes \\
\hline H11695_3 & 2007 & NOAA & $\begin{array}{l}200 / 400 \mathrm{kHz}, \\
240 / 455 \mathrm{kHz}\end{array}$ & $\begin{array}{l}\text { Reson 7125, } \\
8101 \text { \& } 8125 \\
\end{array}$ & $70 \mathrm{~cm}$ & .BAG & No & Yes \\
\hline H12256 & 2010 & NOAA & $300 \mathrm{kHz}$ & $\begin{array}{c}\text { Kongsberg } \\
\text { EM3002 }\end{array}$ & $2 m$ & .BAG & No & Yes \\
\hline H12613 & 2013 & NOAA & $400 \mathrm{kHz}$ & Reson 7125 & $2 m$ & $\begin{array}{c}\text {.BAG, } \\
\text { GeoPDF }\end{array}$ & Yes & Yes \\
\hline H12614 & 2013 & NOAA & $100 \mathrm{kHz}$ & $\begin{array}{c}\text { Reson } 7125 \\
\text { \& Reson } \\
7111\end{array}$ & $2 m$ & $\begin{array}{c}\text { BAG, } \\
\text { GeoPDF }\end{array}$ & Yes & Yes \\
\hline
\end{tabular}




\begin{tabular}{|c|c|c|c|c|c|c|c|c|}
\hline Survey & Survey Year & Agency & Frequency & $\begin{array}{l}\text { Multibeam } \\
\text { System }\end{array}$ & $\begin{array}{c}\text { Highest } \\
\text { Resolution } \\
\text { Available }\end{array}$ & $\begin{array}{c}\text { Multibeam } \\
\& \\
\text { Backscatter } \\
\text { Data } \\
\text { Availability } \\
\text { on NCEI } \\
\end{array}$ & $\begin{array}{l}\text { Included in } \\
\text { the } \\
\text { Backscatter } \\
\text { Mosaic }\end{array}$ & $\begin{array}{l}\text { Included in } \\
\text { Regional } \\
\text { Bathymetric } \\
\text { Synthesis }\end{array}$ \\
\hline H12615 & 2013 & NOAA & $100 \mathrm{kHz}$ & $\begin{array}{c}\text { Reson } 7125 \\
\text { \& Reson } \\
7111\end{array}$ & $2 m$ & $\begin{array}{l}\text {.BAG, } \\
\text { GeoPDF }\end{array}$ & Yes & Yes \\
\hline H12696 & 2014 & NOAA & $\mathrm{N} / \mathrm{A}$ & $\mathrm{N} / \mathrm{A}$ & $2 m$ & $\begin{array}{c}\text {.BAG, } \\
\text { GeoPDF }\end{array}$ & Yes & Yes \\
\hline H12697 & 2014 & NOAA & $\mathrm{N} / \mathrm{A}$ & $\mathrm{N} / \mathrm{A}$ & $8 m$ & $\begin{array}{c}\text {.BAG, } \\
\text { GeoPDF }\end{array}$ & Yes & Yes \\
\hline H12698 & 2014 & NOAA & $\mathrm{N} / \mathrm{A}$ & $\mathrm{N} / \mathrm{A}$ & $2 m$ & $\begin{array}{c}\text {.BAG, } \\
\text { GeoPDF }\end{array}$ & Yes & Yes \\
\hline $\begin{array}{l}\text { W00037 to } \\
\text { W00048 }\end{array}$ & 2003 & NOAA & $95 \mathrm{kHz}$ & $\begin{array}{l}\text { Kongsberg } \\
\text { EM1002 }\end{array}$ & $10 \mathrm{~m}$ & .BAG & No & Yes \\
\hline $\begin{array}{c}\text { W00050 to } \\
\text { W00053 }\end{array}$ & 2003 & NOAA/CCOM & $95 \mathrm{kHz}$ & $\begin{array}{l}\text { Kongsberg } \\
\text { EM1002 }\end{array}$ & $4 m$ & .BAG & No & Yes \\
\hline W00194 SW & 2005 & NOAA/CCOM & $240 \mathrm{kHz}$ & Reson 8101 & $8 m$ & .BAG & No & Yes \\
\hline W00195 NW & 2005 & NOAA/CCOM & $240 \mathrm{kHz}$ & Reson 8101 & $25 \mathrm{~m}$ & .BAG & No & Yes \\
\hline $\begin{array}{c}\text { W00195 } \\
\text { Fippennies }\end{array}$ & 2005 & NOAA/CCOM & $240 \mathrm{kHz}$ & Reson 8101 & $5 m$ & .BAG & No & Yes \\
\hline W00195 Cashes & 2005 & NOAA/CCOM & $240 \mathrm{kHz}$ & Reson 8101 & $5 \mathrm{~m}$ & .BAG & No & Yes \\
\hline H12615 & 2013 & NOAA & $100 \mathrm{kHz}$ & $\begin{array}{c}\text { Reson } 7125 \& \\
\text { Reson } 7111 \\
\end{array}$ & $2 m$ & .BAG, GeoPDF & Yes & Yes \\
\hline $\begin{array}{c}\text { Duxbury to Hull } \\
\text { MA }\end{array}$ & 2007 & NOAA/USGS & $\begin{array}{c}234 / 240 / 455 \\
\mathrm{kHz}\end{array}$ & $\begin{array}{c}\text { SEA } \\
\text { SWATHPlus \& } \\
\text { Reson } 8101 \\
\text { and } 8125\end{array}$ & $5 \mathrm{~m}$ & No & No & Yes \\
\hline
\end{tabular}




\begin{tabular}{|c|c|c|c|c|c|c|c|c|}
\hline Survey & Survey Year & Agency & Frequency & $\begin{array}{l}\text { Multibeam } \\
\text { System }\end{array}$ & $\begin{array}{c}\text { Highest } \\
\text { Resolution } \\
\text { Available }\end{array}$ & $\begin{array}{c}\text { Multibeam } \\
\& \\
\text { Backscatter } \\
\text { Data } \\
\text { Availability } \\
\text { on NCEI }\end{array}$ & $\begin{array}{l}\text { Included in } \\
\text { the } \\
\text { Backscatter } \\
\text { Mosaic }\end{array}$ & $\begin{array}{c}\text { Included in } \\
\text { Regional } \\
\text { Bathymetric } \\
\text { Synthesis }\end{array}$ \\
\hline $\begin{array}{l}\text { Northeast } \\
\text { Atlantic }\end{array}$ & 1999 & NOAA/USGS & $\mathrm{N} / \mathrm{A}$ & N/A & $90 m$ & No & No & Yes \\
\hline W00181 & 2007 & USGS & $240 / 234 \mathrm{kHz}$ & $\begin{array}{l}\text { Reson } 8101 \\
\text { \& SEA } \\
\text { SwathPlus } \\
2000\end{array}$ & $5 m$ & No & No & Yes \\
\hline $\begin{array}{l}\text { Massachusetts } \\
\text { Bay \& } \\
\text { Stellwagen } \\
\text { Bank }\end{array}$ & 1998 & USGS & $95 \mathrm{kHz}$ & $\begin{array}{l}\text { Simrad } \\
\text { EM1000 }\end{array}$ & $10 \mathrm{~m}$ & No & No & Yes \\
\hline $\begin{array}{c}\text { Nahant to } \\
\text { Gloucester } \\
\text { MA }\end{array}$ & 2007 & USGS & $234 \mathrm{kHz}$ & $\begin{array}{c}\text { SEA } \\
\text { Submetrix } \\
2000\end{array}$ & $5 m$ & No & No & Yes \\
\hline $\begin{array}{c}\text { Northern Cape } \\
\text { Cod Bay MA }\end{array}$ & 2007 & USGS & $117 / 234 \mathrm{kHz}$ & $\begin{array}{c}\text { SEA } \\
\text { SwathPlus }\end{array}$ & $5 m$ & No & No & Yes \\
\hline $\begin{array}{l}\text { Northeast } \\
\text { Atlantic }\end{array}$ & & NOAA/USGS & & & & No & No & Yes \\
\hline W00181 & 2007 & USGS & $240 / 234 \mathrm{kHz}$ & $\begin{array}{c}\text { Reson } 8101 \\
\text { \& SEA } \\
\text { SwathPlus } \\
2000\end{array}$ & $5 m$ & No & No & Yes \\
\hline $\begin{array}{c}\text { Massachusetts } \\
\text { Bay \& } \\
\text { Stellwagen } \\
\text { Bank }\end{array}$ & 1998 & USGS & $95 \mathrm{kHz}$ & $\begin{array}{c}\text { Simrad } \\
\text { EM1000 }\end{array}$ & $10 m$ & No & No & Yes \\
\hline
\end{tabular}




\begin{tabular}{|c|c|c|c|c|c|c|c|c|}
\hline Survey & Survey Year & Agency & Frequency & $\begin{array}{c}\text { Multibeam } \\
\text { System }\end{array}$ & $\begin{array}{l}\text { Highest } \\
\text { Resolution } \\
\text { Available }\end{array}$ & $\begin{array}{c}\text { Multibeam } \\
\& \\
\text { Backscatter } \\
\text { Data } \\
\text { Availability } \\
\text { on NCEI } \\
\end{array}$ & $\begin{array}{l}\text { Included in } \\
\text { the } \\
\text { Backscatter } \\
\text { Mosaic }\end{array}$ & $\begin{array}{l}\text { Included in } \\
\text { Regional } \\
\text { Bathymetric } \\
\text { Synthesis }\end{array}$ \\
\hline $\begin{array}{c}\text { Nahant to } \\
\text { Gloucester } \\
\text { MA }\end{array}$ & 2007 & USGS & $234 \mathrm{kHz}$ & $\begin{array}{c}\text { SEA } \\
\text { Submetrix } \\
2000\end{array}$ & $5 m$ & No & No & Yes \\
\hline $\begin{array}{c}\text { Northern Cape } \\
\text { Cod Bay MA }\end{array}$ & 2007 & USGS & $117 / 234 \mathrm{kHz}$ & $\begin{array}{c}\text { SEA } \\
\text { SwathPlus }\end{array}$ & $5 m$ & No & No & Yes \\
\hline
\end{tabular}

